\title{
INVESTIGATION INTO CARNIVOROUS FEEDING NATURE OF PIRANHA (Pygocentrus nattereri) UNDER LABORATORY CONDITION IN BANGLADESH
}

\author{
M. M. R. Khan ${ }^{1 *}$, M. Hasan ${ }^{2}$, M. A. B. Siddik ${ }^{3}$, M. I. Hossain ${ }^{4}$ and
}

M. R. I. Sarder ${ }^{1}$

\begin{abstract}
An experiment was carried out to know the carnivorous feeding nature of piranha (Pygocentrus nattereri) under laboratory condition for a period of 36 days. One-month old nine fish were stocked in nine separate glass aquaria having three feeding treatments each with three replications. Fish were fed with nursery feed (Sabinco feed) in treatment $1\left(\mathrm{~T}_{1}\right) ; 50 \%$ live $+50 \%$ dead small prawns (Macrobrachium rosenbergii) and small fishes (Esomus danricus and Amblypharyngodon mola) in treatment $2\left(\mathrm{~T}_{2}\right)$; and $100 \%$ live small prawn and fishes in treatment $3\left(\mathrm{~T}_{3}\right)$ twice a day at the rate of $10 \%$ body weight. The average weight gain was significantly $(\mathrm{P}<0.05)$ higher in $\mathrm{T}_{2}(21.02 \pm 0.72)$ than in $\mathrm{T}_{1}$ $(-1.824 \pm 0.35)$ and $\mathrm{T}_{3}(15.36 \pm 4.96)$. The SGR $\left(\%\right.$ day $\left.^{-1}\right)$ recorded was significantly $(P<0.05)$ higher in $\mathrm{T}_{2}(12.04 \pm 0.01)$ than $\mathrm{T}_{3}(11.77 \pm 0.09)$. No unused feed was found in $\mathrm{T}_{2}$ and $\mathrm{T}_{3}$ but some unused feed was found in $\mathrm{T}_{1}$. The stomach length, gut length and the RLG values of piranha were significantly $(P<0.05)$ higher than that of taki, Channa punctatus but not of boal, Wallago attu. The presence of razor sharp teeth in both jaws and 30-32 pyloric caeca with 1.84 RLG value are attributed to the piranha as carnivore.
\end{abstract}

Key Words: Piranha, Pygocentrus nattereri, Carnivorous, Thai Rupchanda and SIS

\section{INTRODUCTION}

More than 25 species of piranha are found in the USA, Germany, Brazil and Georgia with the common names of Piranha, Black piranha, Blackspot piranha, Blacktail piranha, Diamant piranha, Lake piranha, Pacu-piranha, Red piranha, Redbelley piranha, Roter piranha, Redeye piranha, San Francisco piranha, Slender piranha, Spotted piranha, White

1 Professor, Department of Fisheries Biology and Genetics, Bangladesh Agricultural University, Mymensingh-2202, Bangladesh

2 Ph.D. Fellow, Laboratory of Amphibian Biology, Faculty of Science, Hiroshima University, Higashi-hiroshima shi, Japan

3 Lecturer, Department of Fisheries Biology and Genetics, Dumki Science and Technology University, Patuakhali, Bangladesh

4 Research Fellow, Department of Fisheries Biology and Genetics, Bangladesh Agricultural University, Mymensingh-2202, Bangladesh

*Corresponding author. E-mail : mmrkhan_bau@yahoo.com 
piranha, Wimple piranha, Yellow piranha etc. (Ferreira et al., 1996). Among them piranha (P. nattereri Cuvier, 1819) is found in the Bolivia, Brazil, Colombia, Venezuela, Guyana as native. Among the species of piranha, P. nattereri is very dangerous (Piorski, 2005) and is abundantly found in the rivers of central and southern South America, east of the Andes including the coastal rivers of the Guyana's, Surinam and Brazil (Jegu, 2003). In the northeast region of Brazil, there has been an introduction of piranha into the small human-made lakes. This fish is renowned for its razor's sharp teeth and its capacity to make skeleton within minute for helpless animals might fall into the water.

Captive redbellies piranha (Serrasalmus spilopleura) can be taught to eat almost everything meaty, ranging from feeders (goldfish, rosy reds, minnows, tetras, basically anything small enough), frozen fish (smelt, cod, catfish, salmon, tuna fish etc.), shrimps, krill, mussels, squid, insects and even small mammals (pinkies, mice etc), reptiles and amphibians. However, the ancestors of piranha were once plant - eaters. Many species of South American redbellies piranha fish, identified by a taxonomist as being very closely related to piranha, use their teeth and strong jaw to eat aquatic plants, and fruit that from overhanging trees. Though some Ichthyologists in the part tried to distinguish between carnivorous piranha and their vegetarian cousin one on the basis of appearance (Anon, 2002).

The fish, piranha was introduced into Bangladesh from Thailand in 2000. At first it was transported to the Gazi Fish Complex in Khulna through Thai fish farmers and it was unknown up to 2003. When the Thai pangas culture became unprofitable then some of fish traders brought this piranha and started to produce seeds commercially in Bangladesh. Some fish farmers have also replaced Thai pangas by piranha in their culture systems. Due to its high growth rate and good taste, this fish has become popular to the people of Bangladesh. Apart from its redbellies colour, this fish looks like Bangladeshi pomfret (Stromateus cinensis), which is avaialable in the marine water of the Bay of Bengal. Within six months piranha attains a weight of $800-900 \mathrm{~g}$ and length of $25-30 \mathrm{~cm}$. It is very dangerous as a form of shoal than a single. Meanwhile, the culture of piranha has been started commercially in some places in Bangladesh. The spawns of piranha were also exported to our neighboring country like India commercially. In the early of 2005, this fish has been recognized as strong predator as fish farmers have reported their dangerous predatory behaviour by discovering the disappearance of small indigenous species (SIS) like as prawn (Macrobrachium rosenbergii), mola (Amblypharyngodon mola), darkina (Esomus danricus), punti (Puntius spp.), dhela (Osteobrama cotio), chanda (Chanda spp.), kholisa (Colisa fasciatus) etc. in the water body like ponds, lakes etc. those accommodated piranha. There is an apprehension that once piranha get a chance to escape from the closed culture ponds to open water bodies they could destroy small indigenous fish (SIS) by eating them. Therefore, the present study was undertaken to know the carnivorous feeding nature of Piranha (P. nattereri) under laboratory condition. 


\section{MATERIALS AND METHODS}

\section{Experimental set up}

The experiment was conducted in the Wet Laboratory of Faculty of Fisheries, Bangladesh Agricultural University, Mymensingh. One-month old nine piranha (average weight $60.01 \pm 6.07 \mathrm{~g}$ and length $15.50 \pm 0.56 \mathrm{~cm})$ were stocked in nine glass aquaria $(45 \times 25 \times 24$ $\mathrm{cm}^{3}$ ) containing $20 \mathrm{~L}$ of deep tube-well water in each and reared for 36 days. The experiment was designed with three treatments $\left(T_{1}, T_{2}\right.$ and $\left.T_{3}\right)$ where each treatment had three replications. Fish were fed by nursery pelleted feed (Sabinco feed) in treatment 1 $\left(\mathrm{T}_{1}\right) ; 50 \%$ live $+50 \%$ dead small prawns (Macrobrachium rosenbergii) and small fishes (darkina, Esomus danricus and mola, Amblypharyngodon mola) in treatment $2\left(\mathrm{~T}_{2}\right)$; and $100 \%$ live small prawn and fishes in treatment $3\left(\mathrm{~T}_{3}\right)$. Two-third water from each aquarium was exchanged with new water twice a day and the fecal output and unused feed were removed from the aquarium by siphoning. Aeration to the aquarium was provided for $22 \mathrm{~h}$ everyday from air blowers and was stopped for one to two hour when feed was supplied to fish.

\section{Feed formulation and application}

Feeds used in three different treatments are shown in Table 1. The analyzed proximate compositions of the different feeds are given in Table 2. Feed was provided in each treatment at the rate of $10 \%$ body weight of piranha. In case of $T_{1}, 55-60$ particles of pelleted feed were given at a time. For $\mathrm{T}_{2}$ and $\mathrm{T}_{3}, 3-4$ prawns, 9-10 darkina and $4-5$ mola were given to the fish in each meal for each treatment. After half an hour of feeding, unused feeds were siphoned out from aquaria and recorded. The feed was given twice (0900 and 1600 h) a day.

Table 1. Three different feeds used for rearing of Piranha during 36 days of experimental period

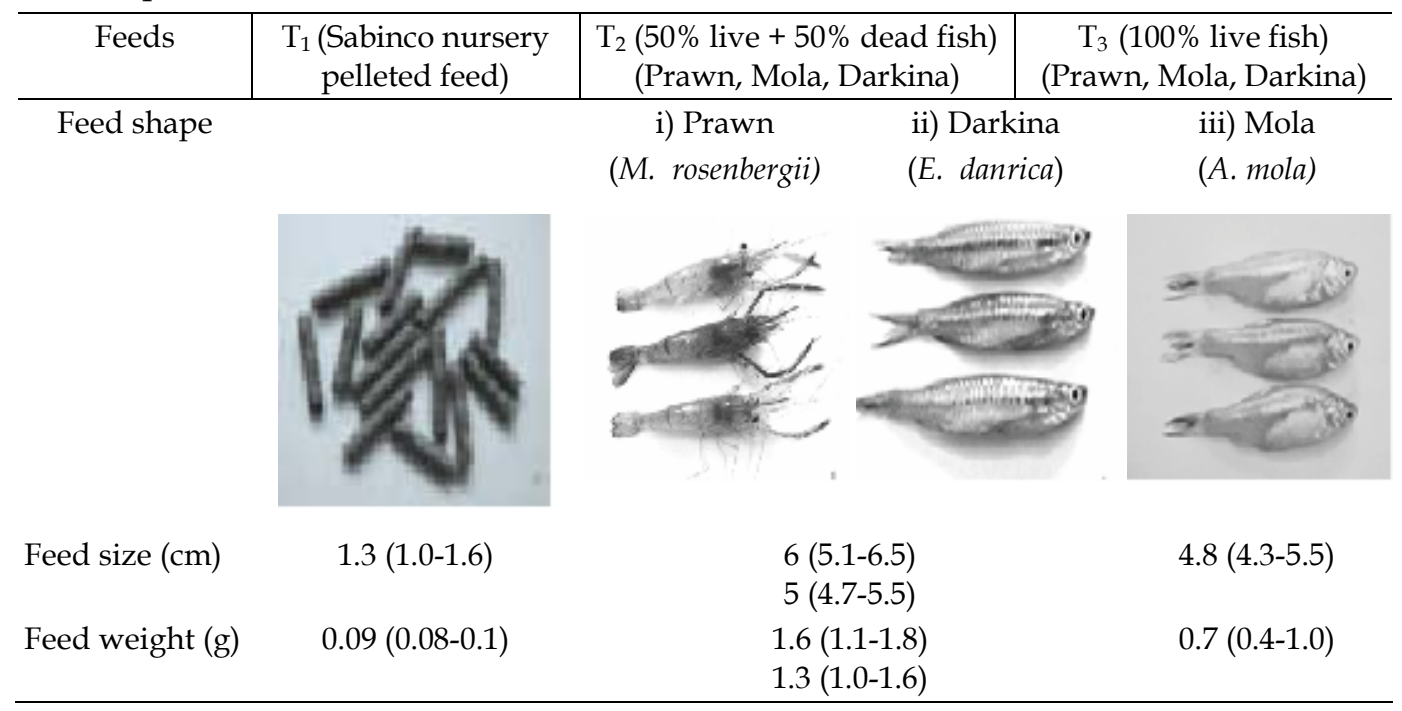


Table 2. Proximate composition (\%) of the different feeds used for rearing of Piranha in 36 days of experimental period

\begin{tabular}{l|c|c|c|c|c|c}
\hline \multirow{2}{*}{ Feed } & \multicolumn{6}{c}{ Parameters (\%) } \\
\cline { 2 - 7 } & $\begin{array}{c}\text { Crude } \\
\text { protein }\end{array}$ & $\begin{array}{c}\text { Other } \\
\text { extract }\end{array}$ & $\begin{array}{c}\text { Crude } \\
\text { fibre }\end{array}$ & Moisture & NFE1 & Ash \\
\hline $\mathrm{T}_{1}$ (pellet feed) & 24.00 & 4.50 & 6.00 & 11.00 & 36.50 & 18.00 \\
$\mathrm{~T}_{2}$ (50\% live + 50\% dead feed) & 55.00 & 5.00 & 3.50 & 18.00 & 10.50 & 8.00 \\
$\mathrm{~T}_{3}$ (live feed only) & 58.00 & 5.00 & 1.50 & 10.00 & 13.50 & 12.00 \\
\hline
\end{tabular}

${ }^{1}$ Nitrogen free extract (NFE) calculated is 100- \% (moisture + crude protein + lipid + ash + crude fibre)

\section{Gut and No. of pyloric caeca}

The stomach length, gut length and the average relative length of gut (ARLG) of piranha was compared with other two native freshwater carnivorous fishes (Boal - Wallago attu and Taki -Channa punctatus). The number of pyloric caeca of piranha was also compared with Boal and Taki to know the carnivorous feeding performance.

\section{Analytical method}

Proximate compositions of feeds of the three different treatments were subject to the estimation of protein, lipid, other extract, crude fiber, NFE and ash by standard methods (AOAC, 1980). The physico-chemical parameters such as dissolved oxygen, $\mathrm{pH}$ and temperature were estimated weekly in the sampling date with the help of Aqua mate water testing kit (Model WAQ-IA).

The fish were sampled in weekly interval to determine the change in their growth (length and weight). Sampling was done in the early morning when the fish stomach was almost empty. The specific growth rate was calculated as the percentage increase in body weight per day over given time interval by the following equation :

Specific growth rate $=\left(\mathrm{LnW}_{2}-\mathrm{LnW}_{1}\right) /\left(\mathrm{T}_{2}-\mathrm{T}_{1}\right) \times 100$

Where, $\mathrm{W}_{2}=$ final live body weight $(\mathrm{g})$ at time $\mathrm{T}_{2}$

$\mathrm{W}_{1}=$ initial live body weight $(\mathrm{g})$ at time $\mathrm{T}_{1}$

The experiment was terminated on $36^{\text {th }}$ day by harvesting the fish from the aquarium and the final growth of the fish was estimated.

\section{Data analysis}

The length gain $(\mathrm{cm})$, weight gain $(\mathrm{g})$, percent length gain, percent weight gain, and specific growth rate, food conversion rate and survival rate during experimentation with different feeds were tested using one way analysis of variance (ANOVA). Significant results $(P<0.05)$ were further tested using Duncan's New Multiple Range Test (DMRT) to identify significant differences among means. This statistical analysis was performed with the aid of the computer software SPSS program. 


\section{RESULTS AND DISCUSSION}

The growth performance i.e. length gain, weight gain, specific growth rate (SGR), food conversion rate (FCR) and survival rate of piranha during the experimental period of 36 days are shown in Table 3. The highest weight and length gain $(21.02 \pm 0.72 \mathrm{~g}$ and 1.2 $\pm 0.08 \mathrm{~mm}$ respectively) of piranha were observed in $\mathrm{T}_{2}$, where $50 \%$ dead and $50 \%$ live feed was used and the lowest $(-1.824 \pm 0.35 \mathrm{~g}$ and $0.33 \pm 0.05 \mathrm{~mm}$ respectively) were observed in $\mathrm{T}_{1}$, where only commercial pelleted feed was used. The SGR values of $\mathrm{T}_{2}(12.3$ $\pm 0.59)$ was significantly $(P<0.05)$ higher than that of $T_{3}(11.77 \pm 0.48)$. The FCR values of $\mathrm{T}_{2}$ (1.961) was lowered than that of $\mathrm{T}_{3}(2.367)$. The survival rate was $100 \%$ in all the treatments (Table 3). Generally the higher feeding frequencies were observed in the early morning except in $\mathrm{T}_{1}$. The weekly feed intake and live weight gain $(\mathrm{g})$ of piranha during 36 days experimental period is shown in Table 4 . In treatment 2, where $50 \%$ dead and $50 \%$ live feeds were used, the feed intake $(41.11 \pm 1.6 \mathrm{~g})$ and live weight gain $(4.85 \pm 0.9 \mathrm{~g})$ were significantly $(\mathrm{P}<0.05)$ higher than that of $\mathrm{T}_{3}(36.36 \pm 1.4 \mathrm{~g}$ and $3.56 \pm 1.7 \mathrm{~g}$ for feed intake and live weight gain respectively), where $100 \%$ live feed was provided.

The gut length, stomach length and the RLG values of piranha compared with boal and taki are shown in Table 5. The gut and stomach length of piranha were significantly $(\mathrm{P}<0.05)$ different from that of taki but not from boal. Similarly, the RLG value of piranha was significantly $(\mathrm{P}<0.05)$ higher than taki. The number of pyloric caeca was found 30, 20 and 2 in piranha, boal and taki respectively. The feeding pattern and behavior with live and dead small fishes (prawns, mola and darkina) was shown in Fig. 1. A. The physicochemical parameters observed in different treatments were more or less same, i.e. water temperature ranged from 24 to $26^{\circ} \mathrm{C}, \mathrm{pH} 8.5$ to 8.7 and dissolved oxygen 5.5 to $6.0 \mathrm{ppm}$ (Table 6).

A new kind of study of feeding behaviour of wild piranhas has been conducted using pelleted feed, live and dead small fishes (prawns, mola and darkina) under the laboratory condition. Even though this fish is newly introduced in Bangladesh and hitched high market demand, it will not be sustained for long time due to its predatory nature on freshwater small indigenous fishes (SIS) or on other animals. The artificial breeding and pond culture of piranha has been propagated in many parts of the country and the people have been started to eat the fish with the name of 'Thai Rupchanda'. The locally popular Rupchanda is marine white pomfret fish, captured from the Bay of Bengal and hitched high price due to its delicious taste. As the piranha was a new exotic fish introduced from Thailand and was completely unknown to the people of Bangladesh, the fish traders took the opportunity to use the fake name of this fish as Thai Rupchanda to catch the attention of people. Therefore, it was necessary to study the fish for its recognition and for understanding its feeding behaviour. The present research work was formulated to know the food and feeding behaviour of piranha and its harmful effect on SIS especially on the biodiversity of SIS in the natural water bodies of Bangladesh. 


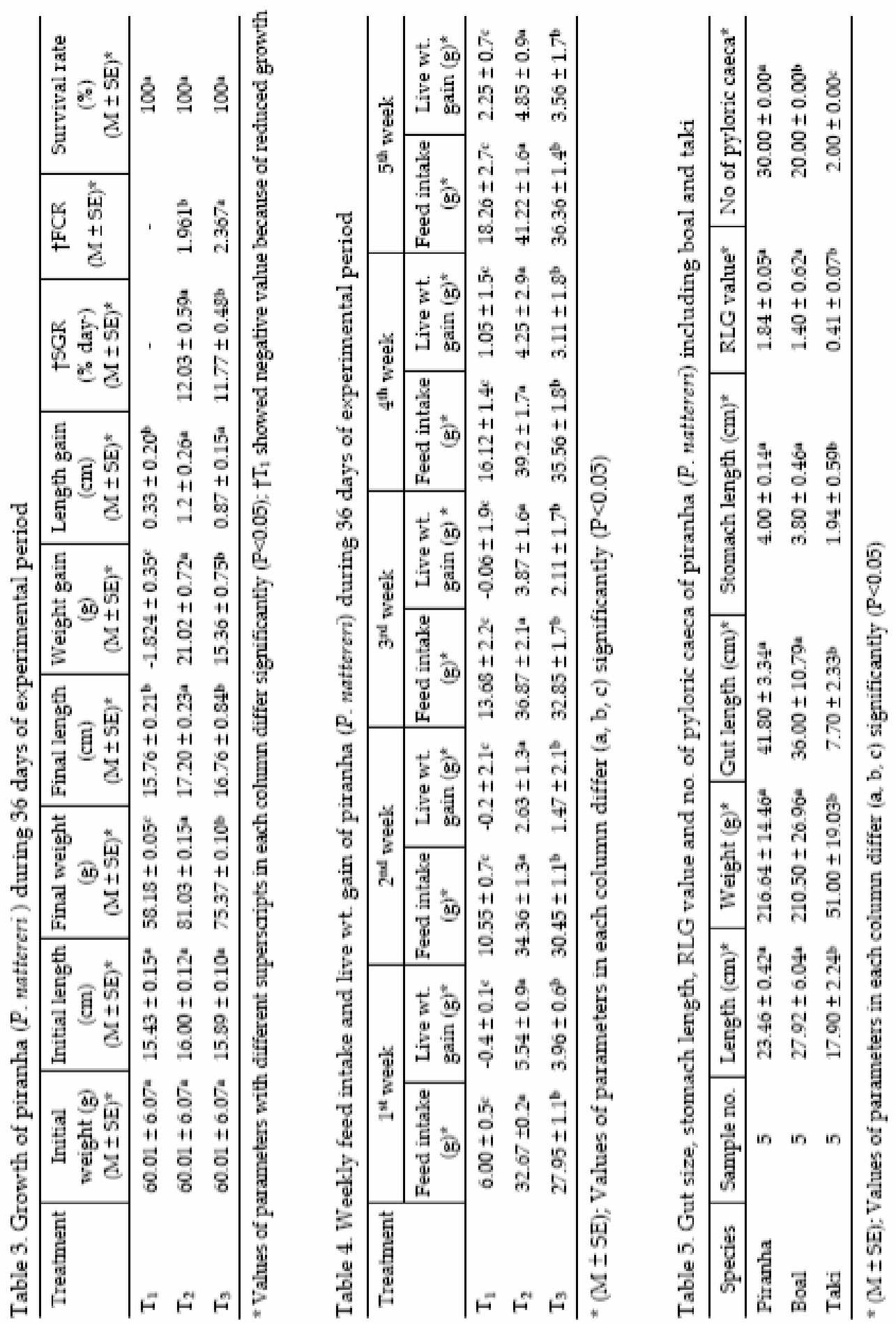


Table 6. Variation in water parameters in aquaria during 36 days of experimental period

\begin{tabular}{l|c|c|c}
\hline \multicolumn{1}{c|}{ Parameters } & $\begin{array}{c}\mathrm{T}_{1} \\
(\mathrm{M} \pm \mathrm{SE})\end{array}$ & $\begin{array}{c}\mathrm{T}_{2} \\
(\mathrm{M} \pm \mathrm{SE})\end{array}$ & $\begin{array}{c}\mathrm{T}_{3} \\
(\mathrm{M} \pm \mathrm{SE})\end{array}$ \\
\hline Temperature $\left({ }^{\circ} \mathrm{C}\right)$ & $23.9 \pm 0.05^{\mathrm{a}}$ & $24.20 \pm 0.08^{\mathrm{a}}$ & $24.20 \pm 0.12^{\mathrm{a}}$ \\
$\mathrm{pH}$ & $8.7 \pm 0.08^{\mathrm{a}}$ & $8.6 \pm 0.10^{\mathrm{a}}$ & $8.5 \pm 0.11^{\mathrm{a}}$ \\
Dissolved oxygen $(\mathrm{mg} / \mathrm{L})$ & $5.5 \pm 0.20^{\mathrm{a}}$ & $5.6 \pm 0.22^{\mathrm{a}}$ & $5.5 \pm 0.15^{\mathrm{a}}$ \\
\hline
\end{tabular}

Values of parameters in each row did not differ $(a, b, c)$ significantly $(P>0.05)]$

In the present study, the highest growth in terms of weight and length was observed in $\mathrm{T}_{2}$ where the piranhas were fed with $50 \%$ live and $50 \%$ dead small prawns (M. rosenbergii) and small fishes (A. mola and E. danricus). Most of the time piranha demonstrated attacking behaviour for catching the live fish and several attempts were taken to do so one after another. In addition, the dead fishes supplied were also found to eat by piranha (Table 4 and Fig. 1). In case of $\mathrm{T}_{3}$, piranha could not take all the supplied live fishes and some unused feeds were found in the aquarium. In the morning, about 20 prawns, darkina and mola were supplied in $\mathrm{T}_{3}$ but they were not taken by a single piranha. The limited space of aquarium and low water volume may interrupt the piranha for free movement and decrease the appetite of fish (Table 4 and Fig. 1). Piorski (2005) studied the feeding behavior of piranha in the Vienna Lake and looked at the qualitative composition of the diet using a frequency occurrence method. He also found that the pacu piranha and redbellies piranha are the eaters of fish or other animals like baby birds. In the treatment 1 , where $100 \%$ pelleted feed was provided, the piranha did not respond well as they do not prefer artificial pelleted feed. As a result, they lost their body weight during 36 days of experimentation (Table 5).

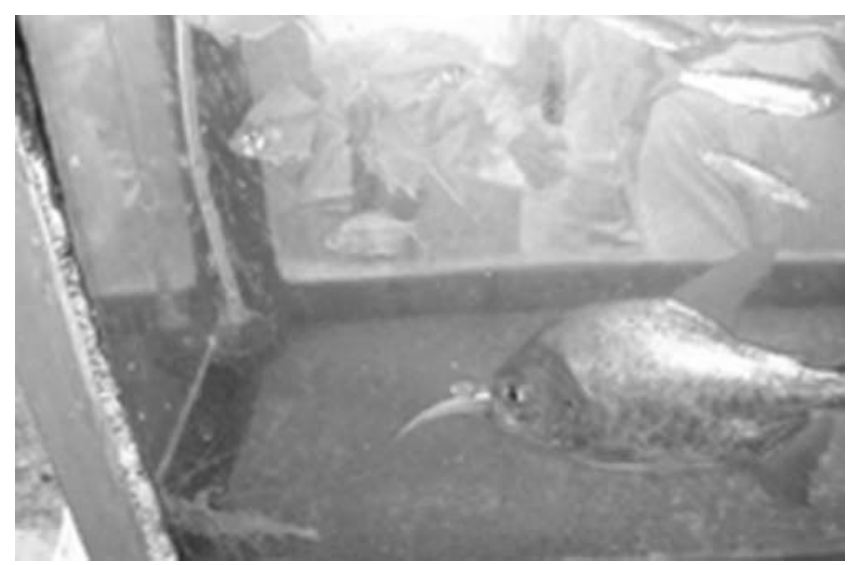

Fig. 1. The feeding pattern and behaviour of piranha with live and dead small fishes in aquarium

The highest length and weight gain of piranha were found in $\mathrm{T}_{2}$ where $50 \%$ supplied dead small fishes were eaten by piranha easily and it got more appetite due to loss of energy for catching $50 \%$ live fishes. But in case of $T_{3}, 100 \%$ live fishes were given to 
piranha where comparatively more energy was used to catch them and the few live fishes were remained in the aquaria. As a result, the weight gain of piranha was lowered in $\mathrm{T}_{3}$ compared to $T_{2}$. Similarly, the higher FCR values were found in $T_{3}$ than in $T_{2}$ which was 1.961. None of the piranha died during experimental period because of their strong predatory nature. For gut analysis of piranha, the gut length, stomach length and RLG value of two freshwater carnivorous fishes i.e., catfish boal, Wallago attu and snakehead taki, Channa punctatus were compared (Table 5). Even though, boal and taki have carnivorous feeding nature but they have some ecoethological balance with freshwater SIS in Bangladesh, whereas piranhas have razor like sharp jaw teeth to prey and chop any fish or animals within a short period. Also piranhas have highest number of pyloric caeca (30) compared to boal and taki for grinding hard food materials. The presence of pyloric caeca and sharp jaw teeth indicates the active predatory feeding behavior of piranha.

During the culture period of piranha (2003-2005) in Bangladesh, it received somewhat importance as an aquaculture species and demand high market price. However, the culture feasibility of piranha in captive as well as in open water bodies raised questions in common people's mind and some reports were published in mass media i.e., television and daily newspapers. In response to the concern of people Department of Fisheries (DoF) took initiative to investigate the feeding behaviour of piranha and its culture feasibility in ponds and other water bodies. There were sporadic reports that the availability of SIS in ponds and other closed water bodies has been reduced remarkably with the introduction of piranha in it. So, the Government of Bangladesh has imposed a ban on artificial reproduction and culture of piranha in any water bodies of Bangladesh with the view to conserve the biodiversity of freshwater fishes specially the small indigenous fishes.

\section{ACKNOWLEDGEMENT}

The authors would like to acknowledge to the Department of Fisheries (DoF), Bangladesh for administrative support to collect data all over the country.

\section{REFERENCES}

Anon. 2002. Fish collection database of the American Museum of Natural History. American Museum of Natural History. Central Park West, NY 10024-5192, USA.

AOAC. 1980. Official methods of analysis. Association of Official Analytical Chemists. 13 ${ }^{\text {th }}$ ed., Washington DC, 1018 pp.

Ferreira, E. J. G., Zuanon, J. and Dos Santos, G. M. 1996. A list of commercial fish species from Santarem, State of Para, Brazil. Naga ICLARM Q., 19(3): 41-44.

Jegu, M. 2003. Serrasalminae (Pacus and piranhas). In: R.E. Reis, S.O. Kullander and C.J.Ferraris, Jr. (eds.). Checklist of the Freshwater Fishes of South and Central America. Porto Alegre: EDIPUCRS, Brasil, 182-196 p.

Piorski, N. M., Alves, J. R. L., Machado, M. R. B. and Correla, M. M. F. 2005. Feeding and ecomorphology of two species of piranhas (Characiformes: Characidae) from the Vienna Lake, Maranhao state, Brazil. Acta Amazonica, 35: 63-70. 